\title{
“有限要素法”入門(その। )*
}

一講義一

水町

渉*

\section{1.はじめに}

最近, エンジニアの間で, 有限要素法とか FEMと かファイナイトという言葉を，しばしば耳にするよう になりました・ただし，この言葉はごく最近流行して きたもので，初めてきく方も多いと思われます．また， 言葉のみで内容については，あまり詳しくない方も多 いと思います．そのような皆様に解説的な本は現在の ところ少なく，大体はマトリックスの式ばかりのもの が多いと思われます.

ここに有限要素法とはなにか，また，どのような方 面に応用されているかなどという点を中心に書いてみ ます. 次回以降は少々進んだ話題をとり入れ, 行列式 も多くなり、コンピュータの限度まで利用した最新の 技術についてもふれてみます.

これを機会に有限要素法とはどのようなものかを理 解していただければ幸いであります.

\section{2. 構造解析の現状とコンピュータ}

この数年に構造解析の分野は大きく進歩し, その様 相は一転した. 最も大きな変化は有限要素法の出現で あると考えられる・しかし，これの根本は電子計算機 の飛躍的進歩によるものである.まず, 図 1 を参照し ていただきたい，1960 年代は演算速度がマイクロ・セ カンド $\left(10^{-6}\right.$ 秒) の単位であったものが, その後半 ならびに 1970 年代は, いよいよナノ・セカンド $\left(10^{-9}\right.$ 秒) の単位に突入している. 今後も電子計算機の進歩 の速度は従来以上のものとなろう．しかし，演算速度 の点では, 今日のコンピュータ回路の速度は, 光の速 度に近い状態である。したがって，演算速度の大幅な 问上は，基本設計上の革新が必要である.コンピュー タの発展の歴史としてよくいわれているのは，第 1 世 代が真空管, 第 2 世代が磁気 Core Transister, 第 3 世代が集積回路（IC，Integrated Circuit）とい うように表現されている，現在，目標とされているつ ぎの世代は, Parallel Computer と Pipeline Computer である.このParallel Computer とは,

* 原稿受付 昭和 47 年 6 月 28 日

** 東京芝浦電気 (株) (東京都千代田区霞ヶ関 3-2-5)
複数のコンピュータを 1 台の駆動ュニットで駆動しよ うというものである.また, Pipeline Computerで は“見かけ上の演算時間は，光の速度で制約されるこ とはなくなる”のである。

話題が少々コンピュータの専門的なことになったが, 今後ともこのように発達していくことである. コンピ ュータの発達により，大きなマトリックス（大次元行 列）を解くことができるようになったのである． 20 年前有名な数学者は, 100 元以上のマトリックスは, どんなコンピュータができても䛊差だらけで解けない と予想していた．しかし筆者はすでに数万元のマトリ ックスを誤差なく解いている。このようにマトリック スが解けるようになったことは，構造解析の分野に大 きな変化を与えた．従来マトリックスというものは， 連立方程式などの式を一つの式で簡単に表わすものと してたいんん便利であったが，実際に解くにはたいへ

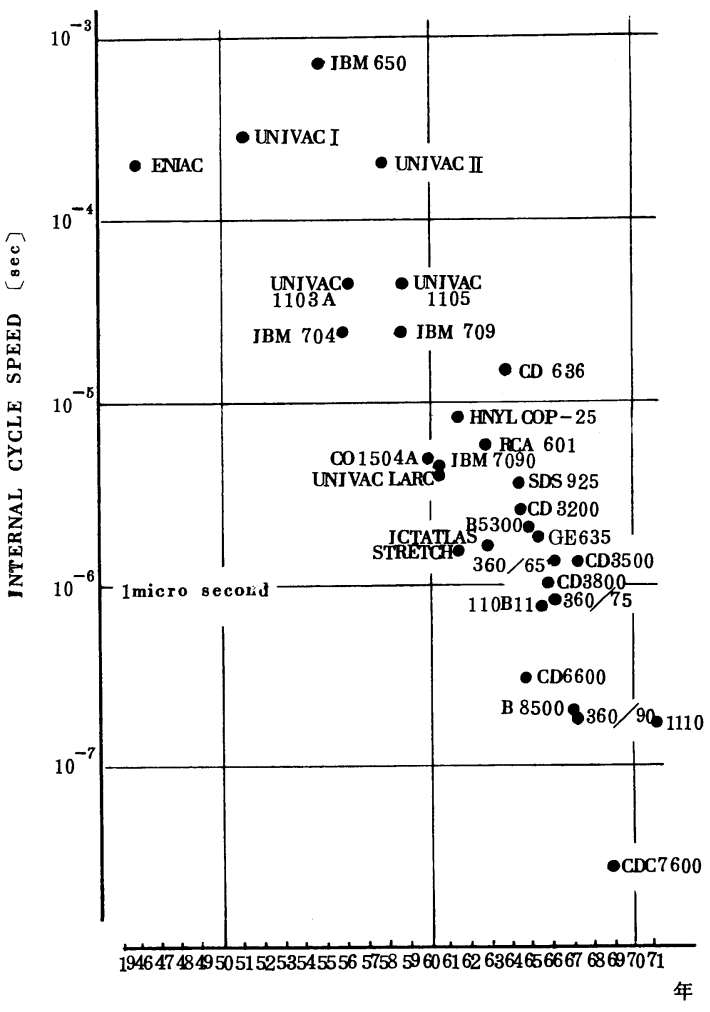

図 1 大形計算機の発達状況 
んな労力を要した・特に次元が大きくなると実際上不 可能であった．これがュンピュータにより解けるよう になり，一般的にマトリックス法というものが発達し たのである.

\section{3. 有 限 要 素 法}

（1）有限要素法とは

有限要素法は今より 18 年前の 1954 年に, Clough, Martin, Turner, Toppにより，はじめてアメリカ の航空学会誌に発表された.それ以前にヨーロッパで も, 現在, 有限要素法の神様といわれている O.C. Zienkiewiczにより研究が進んでいた. したがって， この解析法はまだ生まれて間もないのである．今年の 5 月 Zienkiewicz 教授がはじめて来日された折の講 演会には，多数の土ンジニアが参加した．その際，同 教授と半年ぶりにお目にかかったが，最近の有限要素 法の発達の要因として, 第 1 にコンピュータの発達, そして第 2 に有限要素法の汎用性にあるといっておら れた。

有限要素法はアメリカでは航空機産業から，ヨーロ ッパでは土木関係から発達したが，日本の先駆者は造 船関係からであり, 舶用機関学会には大变縁の深いも のである，それは東大の川井忠彥教授であり，英語の Finite Element Method という言葉を有限要素法 と訳して紹介したのである.現在も造船関係の大プロ ジェクトとして, 有限要素法の汎用プログラムの開発 の先頭に立っておられている.

有限要素法 (Finite Element Method) は最近応 用範囲が広くなってきた。この方法が発表されたのは 前に述べたようにごく最近で，まだ 20 年もたっていな い.その間, 月旅行などの宇宙開発や，大形タンカー の建設, 原子力発電プラントの建設等を中心とした科 学技術の飛躍的発展と, 計算機の発達により有限要素 法は大きく進歩したのである.この方法により, 10 年 前ではおよそ考えられなかった複雑なシステムの構造 解析が可能となり,また種々の非線形問題も大变楽に 解析できるようになったのである.

有限要素法の基本的な考え方は簡単なものである. この分野の権威である Oden 教授 (アラバマ大学) は, 次のように述べている. “有限要素法の根本概念は, 解析しようとする物体を分割していって，その全体の 性質を知るものである.これは何も新しい考えでなく, ピタゴラスにしても日本の江戸時代の数学者が円周率 $\pi$ を計算する際，円を分割して多角形として求めたの と根本的には同じである.”

このように有限要素法という言葉と理論は最近のも
のであるが，根本概念は別に目新しいものではないの である

有限要素法を具体的に振動問題を例にとって説明し てみよう．連続体の振動方程式は次のとおりである.

$$
\frac{\partial^{2} x}{\partial t^{2}}=-\frac{1}{\rho A} \cdot \frac{\partial^{2}}{\partial z^{2}}\left(E I \frac{\partial^{2} x}{\partial z^{2}}\right)
$$

この解は次のとおりである

$$
x=(A \sin \zeta t+B \cos \zeta t)(C \sin \xi Z+D \cos \xi Z
$$$$
+E \sinh \xi Z+F \cosh \xi Z)
$$

ここで

$$
\zeta=\omega
$$

$$
\xi=\sqrt[4]{\frac{\rho \omega^{2}}{E I}}
$$

しかしこれは任意の形状にあてはめることはできな い.これまで実際の問題を解く場合に用いられてきた 方法は本未転倒で，(1)式を満足するように対象物を理 想化して近似解を得ているのである.このような従来 の方法では単体の解析は可能でも, システムの解析は もはや手に負えず新しい解析法が待たれていた．そこ に現われたのがこの有限要素法である.

有限要素法 (Finite Element Method) では, 解 析しようとする物体を有限の大きさの (Finite) 要素 (Element) に分割して，それら相互の関係式から全 体の解析をしょうというものである. このため幾何学 的に複雑なものでも，不均一な物体でも，多様な境界 条件により微分方程式が解けないようなものでも，ま た非線形問題でも解析できるのである.
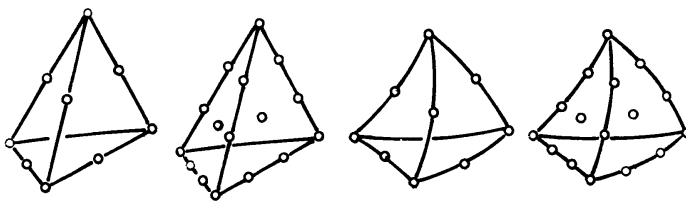

図 23 次元解析用 “有限要素”

\section{（2）諸外国の情勢}

昨年 10 月にアメリカのオ八イオ州デイトンで，有限 要素法に関する国際会議が開かれた（Third Conference on Matrix Methods in Structural

Mechanics). その他りスボンの会議等いろいろな 国際会議が開かれた。また，今年もワシントンをはじ め, この分野の国際会議が続々と開催されている.

このようにヨーロッパ, アメリカの各地で国際会議 が開かれていることは, 最近いかに有限要素法が発達 しているかを物語っている．この方法は変分原理を応 用して解析するものであり，大変汎用性のある方法で ある.そのため, 最初は航空機の振動問題に応用され たが, その後, 建築, 土木, 造船, 原子力, 口ヶット 
等々の構造解析に応用されてきた。一方，そのような 工学の分野を離れ，医学，理学の分野にも適用されて いる．たとえば医学の分野では，高血圧の原因となる 血管内のコレステロールの解析や，目の水晶体の研究 等に応用されている.

オハイオ州に扔けるWright Patterson の会議に は，有限要素法の神様といわれる．O. C. Zienkiewicz 教授をはじめ, Hybrid 法の創始者 M. I. T.の H.H.H.Pian 教授等, アメリカ， ヨーロッパより有 限要素法に関する権威が一同に会していた。筆者も末 席をけがし講演の機会を得たがなかなか迫力のある会 議であった。この会議ではいろいろの角度から，有限 要素法の理論と応用が発表された。ここで感じたのは 日本の実用面での立遅れである.アメリカ，ヨーロッ パでは字宙開発をはじめその他の分野で，有限要素法 はもはや設計のルーティン・ワークとなっている。一 方, 日本ではアメリカ等に比較して, 計算機の質量と もの遅れもあって，理論的にはともかく実用面で相当 遅れをとっていることを実感として受け取った。

\section{4. 有限要素法の応用}

有限要素法は，構造解析のほかさまざまな分野に応 用されている，つぎにどのような解析に使用されてい るか述べてみる.

\section{(1) 応力解析}

現在, 最も広く応用されているのは応力解析の分野 である.船などを例にとれば，その幾何学的形状や境 界条件はたい一ん複雑であり, 従来の応力解析の方法 では大きな仮定なしには解けないものが多かった。ま た，船舶の大形化に伴い，加酷な応力条件からより正 確な応力解析が要求されている，有限要素法はそのよ うな場合，大きな武器となるのである．それは有限要 素法では幾何学的形状や境界条件は全く任意でよいた めである。

また, 一般の応力解析は弾性範用内のものであるが, そ性解析も重要な問題である。そ性解析は従来の方法 では行きずまっていたといっても過言ではないが，こ の有限要素法の出現により簡単に解析できるようにな ったのである.

また，原子力発電プラントを例にとれば，原子炉圧 力率器の設計基準となるアメリカ機械学会の“Boil一 er and Pressure Vessel Code Section III" の “Nuclear Vessels” で, 熱応力のような二次応 カについては Shakedown をおこす範囲 (つまり 2 倍 の降伏伈少をこえない範用) でそ性設計を許している. このため材料非線形の解析も必要である. 有限要素法
はこのような解析が楽にできるのでたいへん有用であ る.

応力解析においては一般に微少変形の弾性問題を考 えている.しかし, システムが複雑になるにつれて， 上に述べたような非線形問題も重要になってくる，応 力解析に関する非線形問題は大きく分けて 2 種類ある 一つはそ性解析などの Material Non-Linearity と よばれる問題であり，もう一つは大変形解析などの Geometrical Non-Linearity の問題である. 両者 とも非常にむずかしい問題であったが，有限要素法に より解析できるようになったのである.

(2) 振動問題

船舶をはじめいろいろな機器を設計する場合, 振動 問題は大きな問題である. しかし，一般の機器系の振 動解析は大変むずかしいものである.(1)式に示したよ うな連続体の振動方程式は理論上のものであり, 普通 の機器の境界条件を入れると，解くことはできなくな ってしまい理想化せざるを得ない，その点，この有限 要素法では, 応力解析のときと同様に, 幾何学的形状 や境界条件は任意でよいので，たいんん有用な方法で ある.

振動問題には一般に 2 段階ある. まず第 1 に固有値 問題で, 固有振動数や固有ベクトルを求める問題であ る．つぎにはある外乱に対する応答計算である．有限 要素法は両者に対して有効な方法である，ただし，応 答計算の場合は, コンピュータの容量の問題で制限が あるのが現状である。

(3) 熱 問 題

舶用機関の設計の際等には熱問題が重要である．熱 応力を計算する場合，まず第一に温度分布を知らなけ ればならない．しかし複雑な形状のものの温度分布を

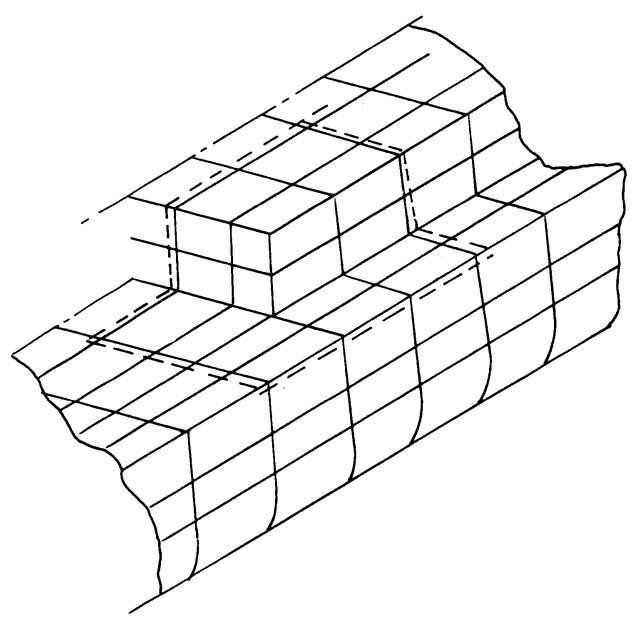

図 3 船の部分図 


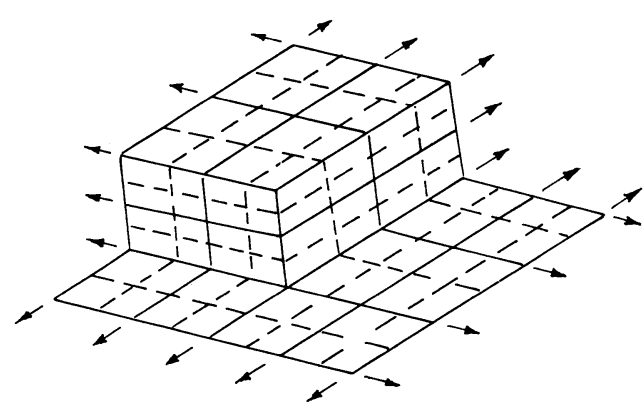

図 4 船の有限要素分割

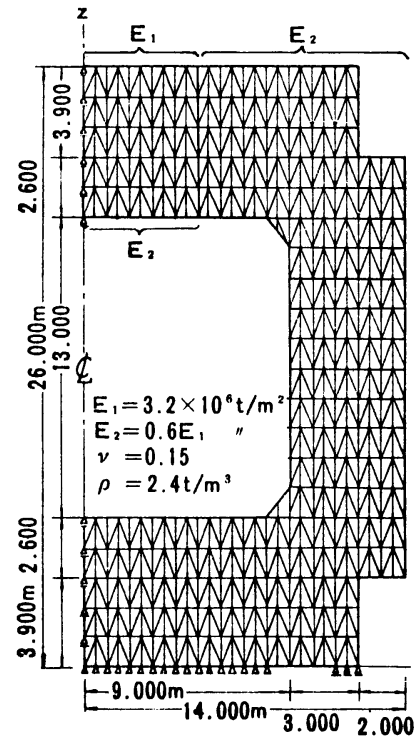

図 5 コンクリート原子炉王力容器 の有限要素分割

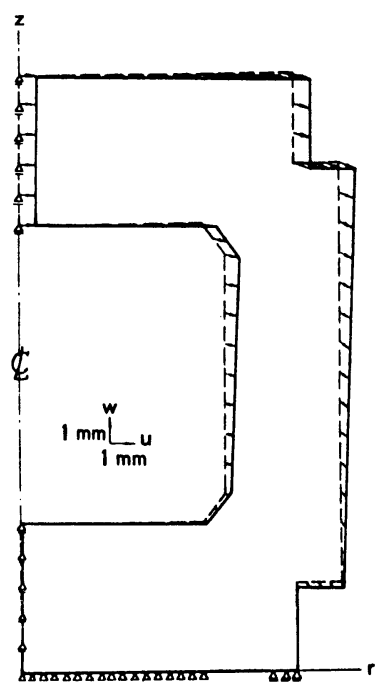

図 6 コンクリート原子炉圧力容器 の地震時の変位（東大川股研）

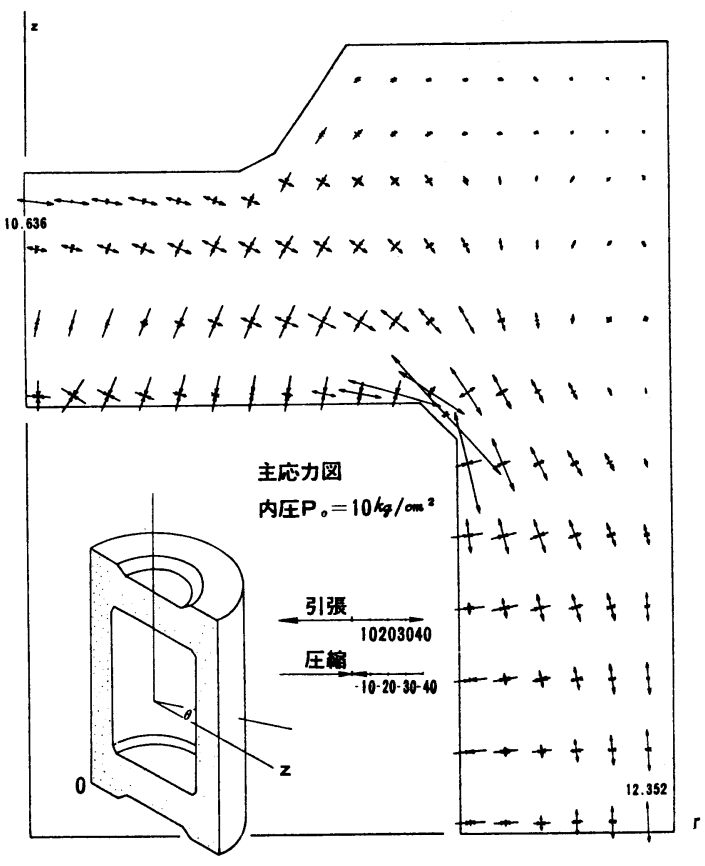

図 7 コンクリート原子炬圧力容器の内王 による応力図 (東大川股研)

計算することはむずかしい問題である．有限要素法は， 任意の形状と任意の境界条件をもつつぎのような問題 にたいへん有用である.

(1) 熱伝達 (Heat Transfer)

(2) 熱伝導 (Heat Conductivity)

(3) $\aleph_{2}<$ 射 ( Radiation)

熱問題では定常状態（Steady State）と過渡状態 (Transient State)の問題がある. 後者の問題なら びに非線形問題は従来むずかしい問題であったが，こ れも有限要素法により同様に解析することができる.

さらに特筆すべきことは, 温度分布を計算すると同じ インプットにより，そのまま熱応力も解析できる点で ある・

（4）その他の分野

以上のほかに, 流体解析, 拡散問題をはじめいろい ろの問題に有限要素法は応用されている.このように 種々の分野に応用されるのは少々奇妙な感じを受ける. これは有限要素法というものが，変分原理を応用した 方法であることによるのである．従来から差分法を使 えばいろいろの問題が解けることはわかっていたが， 差分法は実際に計算する場合に不便な点も多かった。 その差分法に代わるのがこの方法である.

一般に科学計算で, 2 個以上の独立変数の変化率を 含むような問題を定式化すると偏微分方程式となる. 有限要素法はこれの解法であるため, さまざまの分野 
の科学計算に応用されるわけである.

(5) 総論

以上の応用範囲について，式でまとめてみる.

$$
M \ddot{x}+C \dot{x}+K x=R(t)
$$

この式で

$$
\begin{aligned}
M & : \text { 質量マトリックス } \\
C & : \text { 減衰マトリックス } \\
K & : \text { 剛性マトリックス } \\
R(t) & : \text { 外乱 }
\end{aligned}
$$

とする。

(5)式は外乱による振動方程式である.

$$
\begin{array}{r}
\text { ここでまず } \\
C=0
\end{array}
$$

とすると

$$
M \ddot{x}+K x=R(t)
$$

これは減衰のない動的振動問題である.

つぎに

$$
R(t)=0
$$

とすると

$$
M \ddot{x}+K x=0
$$

これは沽有优問題でつぎのようになる。

$$
\left[K-M \omega^{2}\right\rfloor x=0
$$

また，

$$
\left[K_{E}+\lambda K_{G}\right] x=0
$$

は座屈の問題である。

$$
\text { ここで }
$$

$$
K_{E}: \text { Elastic Stiffness Matrix }
$$

$K_{G}$ : Geometrical Stiffness Matrix つぎに(5)式で

$$
K=0
$$

とすると

$$
M \ddot{x}+C \dot{x}=R(t)
$$

これは軌道の問題である.

ここで

$$
R(t)=0
$$

とすれば

$$
M \ddot{x}+C \dot{x}=0
$$

これは弾道の問題である。

$$
\text { つぎに(5)式で }
$$

$$
M=0
$$

とすると

$$
C \dot{x}+K x=R(t)
$$

ここで

$$
\begin{aligned}
C & : \text { Thermal Capacity Matrix } \\
K & : \text { Thermal Conductivity Matrix } \\
R(t) & : \text { Thermal Source }
\end{aligned}
$$

と考えれば $x$ は温度を表わし熱問題となる. 非線形問 題の場合, 熱伝導度は温度により変化すると考えると

$$
C \dot{x}+K(x) x=R(t)
$$

となる。

つぎに(5)式で

$$
\begin{gathered}
M=0 \\
C=0 \\
\text { とすれば } \\
K x=R
\end{gathered}
$$

これは応力解析の式である. $x$ は変位で $R$ は外力を表 わす.

これを非線形問題にすると，まず微少変形をあつかう のでなく，大たわみ問題等の Geometrical NonLinearityを考えると，

$$
K(x) x=R(x)
$$

である。

また弾・そ性問題を考えれば

$$
K(x) x=R
$$

となる・

このように(5)式の変形によりさまざまな問題の方程 式となる。(5)式そのままでも, 弾 · そ性の振動問題は

$$
M(x) \ddot{x}+C(x) \dot{x}+K(x) x=R(t) \cdots \cdots
$$

となる・

この問題に大たわみの問題を加えれば

$$
M(x) \ddot{x}+C(x) \dot{x}+K(x) x=R(x, t)
$$

また熱・弾・そ性問題は

$$
M(x, T) \ddot{x}+C(x, T) \dot{x}+K(x, T) x=R(t)
$$
である。

有限要素法はこのような変分方程式の解法であるた め(正確にいえば汎函数の最小值問題の解法)，いろ いろの問題が解けるのである.

\section{5. おわりに}

有限要素法の最大の利点は, 構造物の幾何学的形状, 材料の特性ならびに境界条件等が任意という点にある。

最近, 有限要素法の発達はめざましく, 今後もより いっそう発展していくと思われる. しかし，ある仮定 をすれば簡単に解けるような問題は, 有限要素法など に頼るべきではない。この方法の創始者の一人である ワシントン大学のMartin 教授自身

"Don't use the elephant gun to shoot a rabit”といっている.

今後, Computer の飛躍的な発展が予想されるが, それにつれより複雑な問題の解析が可能になると考え られる.コーネル大学の Gallagher 教授は，有限要 素法の将来の方向として次の四つをあげている.

(1) 混合問題 
熱力学, 熱伝達, 粘性流体, 非線形振動論等の 組合世問題

(2) 境界条件の多様化

(3) 振動問題

動的解析の簡素化

(4) 非線形問題

\section{各種分野}

次回には, 有限要素法の理論と, 実際どのようにし て解くかという点について述べるつもりである.

\section{参 考 文 献}

(1) Zienkiewicz, O. C., and Cheung, Y. K.: "The Finite Element Method in Structural and Continuum Mechanics" McGraw Hill (1967)

(2) Argyris, J. H., Balmer, H., Doltsinis, J., William, K. J. : "Finite Element Analysis of Thermomechanical Problems" Third Conference on Matrix Methods in Structural Mechanics, Wright-Patterson AFB, Ohio, USA (1971)

(3) Fulton, J. R., "Application of the Finite Element Method to Ship Structural Analysis" JapanU. S. Seminar (1969)

(4) Mizumachi, W. : "Application of Finite Element
Method to the Three-Dimensional Stress and Vibration Analysis of BWR Primary Plant Systems" Structural Mechanics in Reactor Technology, First International Conference, Bundesanstalt für Materialprüfung ( $B A M$ ), Berlin (1971)

(5) Mizumachi, W. : “ Non-Linear Thermal Stress Analysis for Nuclear Power Plant by Finite Element Method" Third Conference on Matrix Methods in Structural Mechanics, Wright-Patterson AFB, Ohio, USA (1971)

（6）川井 忠彦：“マトリックス法振動拉よび応答”培風館 (1971)

(7) 戸川 隼人：“マトリックスの数值計算”オーム社 $(1971)$

（8）平野 菅保ほか：“大次元行列の計算について”東京大学大型 計算機センター $(1970)$

（9）井町 涉：“有限要素法による原子力発電フララントの解析” 日 本銅構造協会 $(1971)$

(10) 水町 涉ほか: “王力容器・配管系の有限要素法による構造解 析” 日本高压力技術協会 (1971)

(11) 水町 涉: “有限要素法の原子力発電ブラントーの応用” 京都 大学数理解析研究所 (1970)

(12) 水町 涉: “有限要素法の数値計算” ソフトウェフ技術 10 月 号, 日本コンピュータ協会 (1971)

(13) 水町 涉: “原子力発電プラントの有限要素解析” 火力発電 5 月号 (1972) 